\title{
The Correlation of Social Media Marketing on Students' Decisions to Use Indonesian Language in Public Areas (A Case Study of Indonesian Literature Students at University of Pamulang)
}

\author{
Tri Pujiati, Ajimat, and Suyatno \\ University of Pamulang, South Tangerang, Indonesia \\ dosen00356@unpam.ac.id
}

\begin{abstract}
Indonesian as a national language has an important role to unite language differences that arise in the community. This phenomenon is interesting to be studies to see the use of Indonesian in the public area which is increasingly diminishing, especially among students. This research is based on the assumption that the use of social media is increasingly developing and widespread which have an impact on the use of Indonesian in the public area. The use of social media that is often found in the community, especially students, is considered to have a relationship with the use of Indonesian itself if the media uses Indonesian language correctly. Therefore, this mix method design research tries to examine the relationship of the use of social media marketing in an effort to attract students to use Indonesian in public area. The numbers of respondents used were 653 students of Indonesian literature studies at University of Pamulang. Analysis of the data in this study used Chi Square and the tool is SPSS 23 program. Based on questionnaire, it can be seen that many students use slang language in social media at about $67 \%$. Based on chi square analysis, it was found that there is a relationship between social media marketing in attracting students to use Indonesian in the public area. These results provide recommendations for the general public to use Indonesian on social media, so the general public is accustomed to using Indonesian language in public area.
\end{abstract}

Keywords: Indonesian Language, Public Area, and Social Media Marketing

\section{Introduction}

Indonesia is a country that has a population of more than 200 people spread to various regions. This diversity makes the different of the speakers' languages because each region has a different language. Looking at the historical facts of the Indonesian language, it can be seen that Indonesian as a unifying language of regional languages so that it is easy to communicate. This is what underlies the Indonesian as a language of unity which was formalized on October 28,1928 in the pledge of youth oaths. However, this history seems to change along with the times and also technological developments. The use of Indonesian is increasingly eroded by the use of slang, especially among adolescents who rarely use Indonesian, especially in public areas. The thing that underlies the interest of this research is the existence of a new phenomenon that teenagers are more likely to use slang than Indonesian, especially when they are in public areas which can certainly disrupt the existence of Indonesian language itself.

The development of technology makes information can be conveyed quickly and it cannot be denied that the presence of this technology is able to facilitate humans in carrying out communication activities; one of the uses of the technology is the existence of the internet. 
This tool is able to change all aspects of life because everything can be found easily by using the internet. Social media in cyberspace, such as Twitter, Facebook, blogs, and online discussion forums today are very popular with the world community, Nugraheni (2017: 4). Social media is now present as a communication tool that is always inherent in human life and all aspects of human life are often discussed through social media in accordance with its function, namely a tool to convey ideas or thoughts into social life. The media has an extraordinary influence in spreading news to the public. The media is a group tool to manipulate the non-dominant, Eriyanto (2005: 22- 23). The media is also a marker of human civilization in representing information, Danesi (2010: 276). In the context of social movement activities, this technological change also changes activists in communication, Sanjaya (2018: 17- 32). In spreading information, the media is supported by modern communication technology entrepreneurs and the commercial information industry, Lull (1997: xxvii). Media has a function as information providers and social critics to relevant agencies to immediately fix themselves in the political process, Pujiati \& Yulianti (2019).

Unfortunately, the advancement and sophistication of this technology is not always accompanied by positive things. Often social media is used to blaspheme or express hate speech. In the case of language use too, many social media are more often using slang so that the current millennial generation is more interested in using slang when speaking in the public area. This has become a concern for researchers considering that social media has an important role in the delivery of information and dissemination of Indonesian language to the general public. Octorina, I. M., Karwinati, D., \& Aeni, E. S. (2019) conducted a study and found that social media in this era is a container where users can express their expressions and desires, especially among teenagers. Research conducted by Nugrahani (2017) shows that there are deviations in the use of pragmatic language in political propaganda uploaded through social media. Samsudin (2015) conducted a study which showed that the media has a very large role in correcting the Indonesian term. Derakhshan, A., \& Hasanabbasi, S. (2015), The review would conclude that social interaction via social networks is a kind of stimulus for learners to communicate with others. Bakeer (2018) found that social media had a positive effect in developing students' writing skills.

Based on this background, researchers are interested in conducting studies related to the influence of social media marketing in an effort to influence students' decisions to use Indonesian in the public area. This is very important to do given that social marketing is very influential in the decision to use a product, one of which is the use of Indonesian. Several previous studies related to the decision to use the product have been carried out using these variables as an effort to see the decision to use the product, including L Moriansyah (2015), Nugraha, etal (2015), Pratama (2017), Mahdiasukma and Fauzi (2018), Mileva and Fauzi DH (2018), and Joesyiana (2018), Ajimat (2020). This research tries to look at the effect of social media marketing to see the decision of students to use Indonesian in the public area. This study specifically will narrow the problem to social media marketing relations in attracting students' interest in using social media in an effort to use Indonesian in the public area.

\section{Method}

This study seeks to see the effect of social media marketing on student decisions in using Indonesian in the public area. The object of study in this study was a number of students in the Indonesian Literature Study Program at University of Pamulang with a sample of 653 
espondents. The initial assumption of the selection of study objects by using Indonesian literature study program students is on the basis that students in this study program specifically study Indonesian language and literature in their learning activities so that they have a strong desire to use Indonesian in the public area especially as an effort to maintain their existence Indonesian so as not to become extinct by the times.

This research uses a mix method approach as an effort to see the description related to the use of social media among students and to examine the effect of the $\mathrm{X}$ variable with the $\mathrm{Y}$ variable. This study uses primary data obtained through research instruments, a questionnaire distributed to students in the Indonesian Literature Study Program using random sampling. The data analysis technique used to test the hypothesis is to use the chi square test with SPSS 23 program tools.

\section{Findings and Discussion}

Based on research findings on the use of social media by respondents, it can be seen several social media used by them to interact with others. Consider the following diagram:

\section{Social Media used by Student}

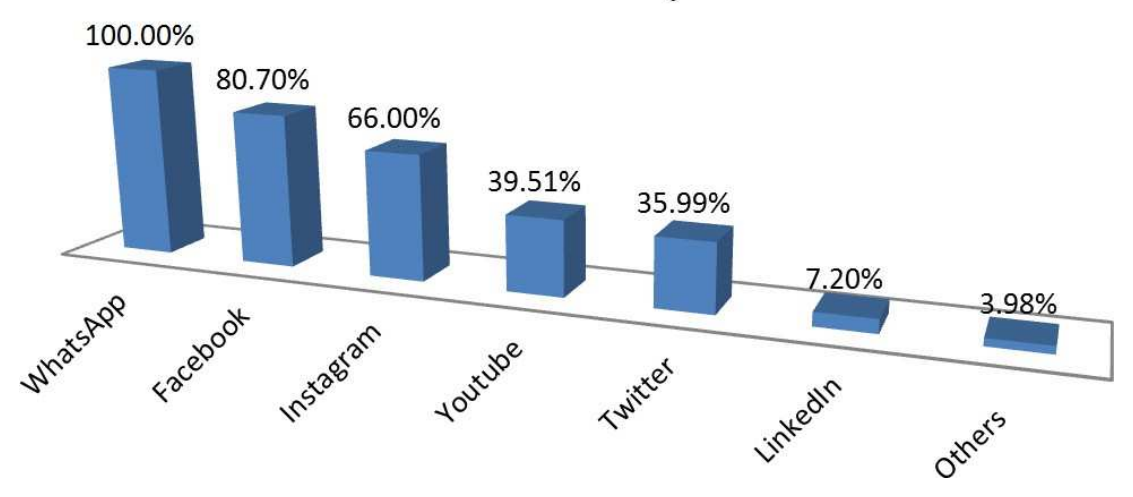

Fig.1. Social Media Used by Indonesian Literature Study Program Students

Based on the results of data processing on the questionnaire given, it can be seen that the most widely used social media by students in Indonesian literature study programs is Whatsupp. It is proven that 100 percent of students prefer to use WA to communicate. The face book (FB) as much as $80.7 \%$, Instagram (IG) as much as $66 \%$, Youtube as much as $39.51 \%$, Twitter $35.99 \%$, LinkedIn as much as $7.20 \%$, and others as much as $3.98 \%$. Based on the results of data processing on the use of social media that is widely used by these students, it can also be seen that students have more than one social media and even more than 4 social media are used. Along with the distribution of the many social media used by students: 


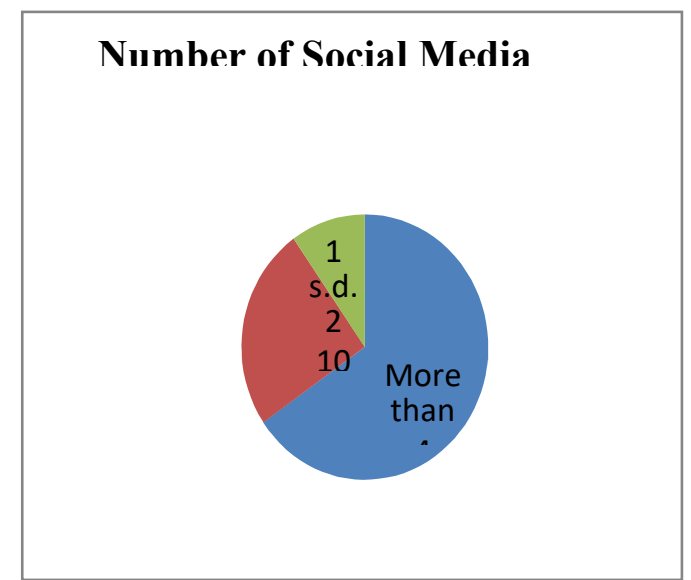

Fig.2. The Number of Social Media Used by Indonesian Literature Study Program Students

Based on diagram 2 above, it can be seen that around $10 \%$ of students use 1 to 2 social media in communication activities, while $25 \%$ of the total respondents are proven to use 3 to 4 social media in their lives. $65 \%$ more students use more than 4 social media in their daily lives. This proves that the dissemination of information and the use of language can have positive implications for the use of social media, moreover that many students use more than 4 social media in their lives. In using social media, it certainly cannot be separated from the language used by these students to express their ideas and ideas. Given that language is the most effective medium for conveying ideas. The most widely used language on social media can be seen in the following diagram:

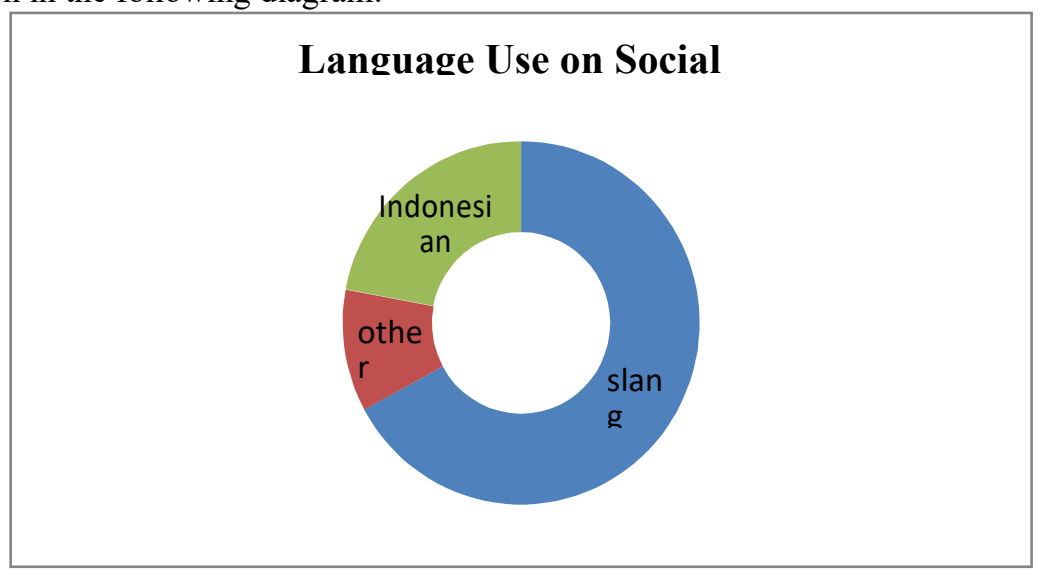

Fig.3. Language Used by Indonesian Literature Study Program Students in Social Media

Based on diagram 3 above, it can be seen that more than $67 \%$ of students use slang when communicating on social media. The using of Indonesian language as a communication tools on social media as much as $22 \%$ and the use of other languages $11 \%$. From these findings, it can be seen that students tend to prefer to use slang when communicating with others. In line with the foregoing, it appears that the use of Indonesian is still rarely used by 
students so this study tries to look at the relationship of the use of social media marketing to the decision of students to use Indonesian in the public area. The hypotheses proposed in this study are:

a) Ho: There is no relationship between social media marketing and the decision of students to use Indonesian in public areas

b) Ha: There is a relationship between social media marketing and the decision of students to use Indonesian in public areas

Based on the hypothesis test, the chi square test is performed as shown in the following data processing:

Table 1. Case Processing Summary

\begin{tabular}{lcccccc}
\hline & \multicolumn{5}{c}{ Cases } \\
\cline { 2 - 7 } & \multicolumn{2}{c}{ Valid } & \multicolumn{2}{c}{ Missing } & \multicolumn{2}{c}{ Total } \\
\cline { 2 - 7 } & N & Percent & N & Percent & N & Percent \\
\hline Medsos (Bahasa) & 653 & $100,0 \%$ & 0 & $0,0 \%$ & 653 & $100,0 \%$ \\
\hline
\end{tabular}

Table 2. Medsos * Bahasa Crosstabulation

\begin{tabular}{lcccccc}
\hline & & \multicolumn{3}{c}{ Bahasa } & \\
\cline { 3 - 6 } & & & Indonesia & Lainnya & Gaul & Total \\
\hline Medsos & 1 s.d. 2 & 16 & 37 & 11 & 64 \\
& 3 s.d. 4 & 91 & 26 & 45 & 162 \\
& Lebih dari & dari 4 & 37 & 8 & 382 & 427 \\
\hline \multicolumn{2}{l}{ Total } & & 144 & 71 & 438 & 653 \\
\hline
\end{tabular}

Table 3. Chi-Square Tests

\begin{tabular}{llll}
\hline & Value & Df & $\begin{array}{l}\text { Asymptotic Significance (2- } \\
\text { sided) }\end{array}$ \\
\hline Pearson Chi-Square & $378,918^{\text {a }}$ & 4 &, 000 \\
Likelihood Ratio & 331,559 & 4 &, 000 \\
Linear-by-Linear & 174,520 & 1 &, 000 \\
$\begin{array}{l}\text { Association } \\
\text { N of Valid Cases }\end{array}$ & 653 & & \\
\hline
\end{tabular}

a. $\quad 0$ cells $(0,0 \%)$ have expected count less than 5 . The minimum expected count is 6,96 .

Based on the above calculation, it can be seen that the Asymp value. Sig. Chi-Square is smaller than 0.05 . So, Ho is rejected and $\mathrm{Ha}$ is accepted. This means that there is a relationship between social media marketing and the student's decision to use Indonesian in the public area. So, tt can be concluded that marketing or promotion using social media related to the use of Indonesian will be more effective if using social media. Therefore, it is important for students to get used to using Indonesian properly when using social media so that they will get used to using Indonesian in the public area. 


\section{Conclusion}

Based on the findings and discussion above, it can be concluded that students in the Indonesian Literature study program at University of Pamulang use social media especially WA in their communication activities. However, in their daily life it can be seen that many students use slang in communication activities. Therefore, it is very clear that the use of Indonesian language is still less in demand by students of Indonesian literary study programs so that efforts need to be promoted through social media marketing, especially in the use of Indonesian in the public area. In the next discussion, testing the hypothesis showing that there is a relationship between social media marketing and the decision of students to use Indonesian in the public area. It can be concluded that marketing or promotion using social media related to the use of Indonesian will be more effective if using social media.

\section{Acknowledgments}

The author would like to thank the head of the research institute and community service at University of Pamulang and the chair of the Sasmita Jaya Foundation for supporting this research. Thank you also to the reviewers who have provided input in writing this article.

\section{References}

[1] Ajimat, A. (2020). Analisis Perbandingan Word Of Mouth Marketing dan Social Media Marketing dalam Menarik Minat Mahasiswa dalam Memilih Universitas (Studi Empiris pada Mahasiswa Universitas Pamulang). Jurnal Pemasaran Kompetitif, 3(2), 23-30.

[2] Bakeer, A. M. (2018). Effects of Information and Communication Technology and Social Media in Developing Students' Writing Skill: A Case of Al- Quds Open University. International Journal of Humanities and Social Science, 8(5), 45-53.

[3] Danesi, Marcel. (2010).Pengantar Memahami Semiotika Media, Terj. A. Gunawan Admoranto. Yogyakarta: Jalasutra.

[4] Derakhshan, A., \& Hasanabbasi, S. (2015). Social networks for language learning. Theory and Practice in Language Studies, 5(5), 1090-1095.

[5] Eriyanto.(2015). Analisis Wacana; Pengantar Analisis Teks Media. Yogyakarta: LkiS.

[6] Ilham Adji Putra Pratama, I. (2017). Komunikasi Word of Mouth dan Keputusan Pembelian Produk Batik Bangkalan. Komunikasi Word of Mouth dan Keputusan Pembelian Produk Batik Bangkalan, 3(2), 285-295.

[7] Joesyiana, K. (2018). THE EFFECT OF WORD OF MOUTH ON CONSUMER PURCHASING DECISIONS AT SHOPEE (ONLINE SHOP) IN PEKANBARU. VALUTA, 4(1), 71-85.

[8] Lull, James. (1997). Media, Komunikasi, Kebudayaan: Suatu Tinjauan Pendekatan Global, Terj. A. Setiawan Abdi. Jakarta: Yayasan Obor Indonesia.

[9] Mileva, L., \& Fauzi DH, A. (2018). Pengaruh Social Media Marketing Terhadap Keputusan Pembelian (Survei Online pada Mahasiswa Sarjana Jurusan Ilmu Administrasi Bisnis Angkatan 2014/2015 Fakultas Ilmu Administrasi Universitas Brawijaya yang Membeli Starbucks Menggunakan LINE). Jurnal Administrasi Bisnis, 58(1), 181-189.

[10] Moriansyah, L. (2015). PEMASARAN MELALUI MEDIA SOSIAL: ANTECEDENTS DAN CONSEQUENCES SOCIAL MEDIA MARKETING: ANTECEDENTS AND ISSN N0. 
(PRINT) 2598-0823,

[11] (ONLINE) 2598-2893 Kompetitif Jurnal Pemasaran Jurnal Pemasaran Kompetitif, Vol. 3, No. 2 / Februari 202030 CONSEQUENC-ES. Jurnal

[12] Penelitian Komunikasi dan Opini Publik Vol, 19(3), 187- 196.

[13] Nugrahani, F. (2017). Penggunaan Bahasa dalam Media Sosial dan Implikasinya terhadap Karakter Bangsa. Stilistika: Kajian Bahasa, Sastra, dan Pembelajarannya, 3(1).

[14] Octorina, I. M., Karwinati, D., \& Aeni, E. S. (2019). PENGARUH BAHASA DI MEDIA SOSIAL BAGI KALANGAN REMAJA. Parole (Jurnal

[15] Pendidikan Bahasa dan Sastra Indonesia), 1(5), 727-736.

[16] Prenhallinda Mahdiasukma, P., \& Fauzi, A. (2018). Pengaruh Word of Mouth Marketing terhadap Keputusan Pembelian (Survei pada Konsumen Coffee Toffee cabang Kota Malang). Jurnal Administrasi Bisnis, 55(3), 55-63.

[17] Pujiati, T., \& Yulianti, D. M. (2019). Mesostructural and Macrostructural Analysis of Setya Novanto Case on Online Detikcom Media. Jurnal Ilmiah Humanika, 2(1), 22-29.

[18] Samsudin, D. (2015). Peran Media Dalam Pemasyarakatan Istilah Bahasa Indonesia. Metalingua, Vol. 13 No. 2, Desember 2015:151-159

[19] Sanjaya, A. R. -Petisi Indonesia Untuk Dunia: Potret Globalisasi Gerakan Sosial Digital.॥ Jurnal Komunikasi 10, no. 1 (2018): 17-32. 